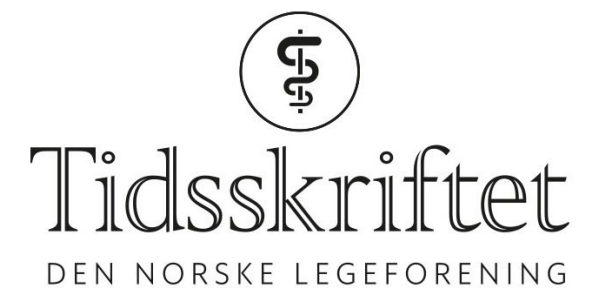

DEN NORSKE LEGEFORENING

\title{
Hva kan gjøres for å forebygge forsinket diagnostikk av diabetes type 1 hos barn?
}

DEBATT

TORILD SKRIVARHAUG

Torild Skrivarhaug (f. 1963) er dr.med. og overlege ved Barne- og ungdomsklinikken, Oslo universitetssykehus, og leder av Nasjonalt medisinsk kvalitetsregister for barne- og ungdomsdiabetes. Hun er også tilknyttet Oslo Diabetes Forskningssenter ved Oslo universitetssykehus. Forfatter har fylt ut ICMJE-skjemaet og oppgir følgende interessekonflikter. Hun har mottatt honorar fra Lilly og Novo Nordisk. Begge firmaene produserer insulin.

\section{KETIL STØRDAL}

Ketil Størdal (f. 1966) er dr.med., seniorforsker ved Folkehelseinstituttet og overlege ved Barne- og ungdomsklinikken, Sykehuset Østfold. Han er leder i Norsk barnelegeforening. Forfatter har fylt ut ICMJE-skjemaet og oppgir ingen interessekonflikter.

\section{LARS CHRISTIAN STENE}

E-post: lars.christian.stene@fhi.no Lars Christian Stene (f. 1971) er dr.philos, epidemiolog og seniorforsker, og han leder forskningsprosjekter om risikofaktorer ved type 1-diabetes ved Avdeling for barns helse, Folkehelseinstituttet. Han er også tilknyttet Oslo Diabetes Forskningssenter ved Oslo universitetssykehus.

Forfatter har fylt ut ICMJE-skjemaet og oppgir ingen interessekonflikter.

Flere norske barn og unge med nyoppdaget diabetes type 1 har ketoacidose sammenlignet med barn i Sverige og Danmark. Økt oppmerksomhet og kunnskap om klassiske diabetessymptomer i befolkningen og blant helsepersonell kan trolig forebygge flere tilfeller av ketoacidose.

Fra samtaler med pasienter med type 1-diabetes og deres familier vet vi at en del har hatt klassiske symptomer i lang tid før behandling ble igangsatt. Sannsynligvis kunne diagnosen vært stilt tidligere og ketoacidose unngått - dersom pårørende og helsepersonell hadde gjenkjent symptomene tidligere. Vi ønsker med denne artikkelen å rette oppmerksomheten mot diabetessymptomer og å gi en oppdatering om nyere forskning på det naturlige forløpet ved type 1-diabetes.

Diabetes defineres ved høyt blodsukker, som ved type 1-diabetes skyldes immunmediert $\emptyset$ deleggelse av de insulinproduserende betacellene i bukspyttkjertelen. Unormal tørste, slapphet, vekttap, hyppig vannlating og nyoppstått sengevæting er klassiske, men uspesifikke symptomer på diabetes. Ved slike symptomer er det viktig å utrede for diabetes ved å sjekke blodglukose og $\mathrm{HbA}_{\mathrm{tc}}$. I henhold til retningslinjene er $\mathrm{HbA}_{\mathrm{cc}}$-verdi > = 6,5\% 
generelt anbefalt diagnosekriterium $(1,2)$.

Hos barn og unge med nyoppdaget type 1-diabetes ligger $\mathrm{HbA}_{\mathrm{cc}}$-verdien som regel langt over grenseverdien (upubliserte data fra Barnediabetesregisteret), men trolig kan noen barn og unge med raskt sykdomsforløp sannsynligvis også ha diabetes ved lavere verdier enn $6,5 \%$ (3). Derfor brukes ofte i praksis blodglukoseverdi $>=11,1 \mathrm{mmol} / \mathrm{l}$ som diagnostisk kriterium, og de aller fleste barn med nyoppdaget type 1-diabetes har verdier langt over 11,1 mmol/l, kombinert med klassiske symptomer (4).

Når det ikke foreligger klassiske symptomer, skal $\mathrm{HbA}_{\mathrm{tc}}$ eller blodglukose sjekkes en annen dag for å kunne stille diagnosen $(1,4)$. Både ved sikker diagnose og ved tvil skal pasienten innlegges akutt i en barneavdeling (ved alder 0-18 år), uansett klinisk tilstand (5). I Norge henviser som regel fastlegen barnet til sykehus samme dag, og innleggelsen med opplæring varer gjerne i én til to uker. Rask diagnostikk og behandling er viktig for å unngå diabetisk ketoacidose.

\section{Diabetisk ketoacidose}

Diabetisk ketoacidose (syreforgiftning) defineres biokjemisk ved lav pH-verdi og lavt nivå av bikarbonat i blodet, kombinert med høye konsentrasjoner av glukose og ketoner i urin og/eller blod (6). På bakgrunn av pH-nivå og bikarbonatnivå deles diabetisk ketoacidose inn i mild, moderat og alvorlig.

Symptomer ved diabetisk ketoacidose kan være uspesifikke, for eksempel tørste, magesmerter, kvalme og oppkast. Ved klinisk undersøkelse finner man gjerne unormalt rask pust, dyp hyperventilasjon (Kussmauls respirasjon), acetonlukt, sløret bevissthet, dehydrering, lavt blodtrykk, hurtig puls og koma. Moderat eller alvorlig ketoacidose (definert ved $\mathrm{pH}$-verdi $<7,2 \mathrm{og} /$ eller bikarbonat $<10 \mathrm{mmol} / \mathrm{l}$ ) skal behandles ved en medisinsk intensivavdeling.

Data fra Barnediabetesregisteret (Nasjonalt medisinsk kvalitetsregister for barne- og ungdomsdiabetes) viser at rundt 90 av totalt ca. 37o barn i alderen o-17 år som legges inn med nyoppdaget type 1-diabetes, har ketoacidose (7). En ny studie fra registeret og tilsvarende registre i våre naboland viser at i alderen o-14 år er andelen med ketoacidose ved diagnose noe høyere i Norge (23,5\%) enn i Danmark (20,4\%) og Sverige (20,5\%) (8). Forskjellen til nabolandene er mer uttalt for andelen pasienter med alvorlig diabetisk ketoacidose (definert ved venøs $\mathrm{pH}$-verdi $<7,1$ og bikarbonat $<5 \mathrm{mmol} / \mathrm{l}$ ): 7,1 \% i Norge og 1,7 \% i Danmark (8). Det er uklart hva som forklarer denne forskjellen. Hvert år utvikler ca. 6o personer (ca. $16 \%$ ) i aldergruppen o-17 år med nyoppdaget type 1-diabetes med moderat eller alvorlig diabetisk ketoacidose.

Det er umulig å sette en operasjonell definisjon for nøyaktig når diabetesdiagnosen «bør» settes og dermed når det er «forsinket». Utvilsomt er ketoacidose ved diagnose uønsket og et tegn på forsinket diagnose. Da har man temmelig sikkert gått en stund med klassiske symptomer på diabetes som kunne vært gjenkjent av pasient, pårørende eller helsepersonell, slik at behandling med insulin kunne ha startet tidligere. Da kunne ketoacidose sannsynligvis vært unngått eller hatt mindre alvorlighetsgrad. For mange kan innleggelse i intensivavdeling være en skremmende start på en livslang sykdom både for barnet og familien. I tillegg kommer høye kostnader ved slik innleggelser (6). I den andre enden av det kliniske spektret finner vi diabetesassosiert autoimmunitet uten hyperglykemi eller andre symptomer, som kan oppdages ved screening.

\section{Screening}

Ulike former for screening vil kunne identifisere type 1-diabetes tidligere i forløpet. Screening kan være prediktiv (genetisk test eller diabetesassosierte autoantistoffer forbundet med $\emptyset \mathrm{kt}$ risiko for diabetes i fremtiden) eller baseres på diagnostiske tester som $\mathrm{HbA}_{\mathrm{tc}}$ eller blodglukose. 
Befolkningsbasert screening med diagnostiske tester er problematisk fordi personer med negativ test i prinsippet likevel kan utvikle diabetes etter relativt kort tid. En negativ screeningtest for diabetesassosierte autoantistoffer vil kunne utelukke type 1-diabetes for noen måneder i fremtiden, men prediktiv testing er problematisk fordi man ikke kan sette i gang forebygging eller behandling før pasienten har hyperglykemi. Uansett ville en befolkningsbasert screening for type 1-diabetes være svært ressurskrevende.

Basert på dagens kunnskap vil vi ikke foreslå befolkningsbasert screening for type 1-diabetes av barn og unge. Derimot kan screening som ledd i forskningsstudier gi verdifull informasjon om sykdommens naturlige forløp. I de neste avsnittene oppsummerer vi nyere forskning på dette feltet.

\section{Tidlige metabolske forandringer}

Screeningstudier med gjentatte målinger av $\mathrm{HbA}_{\mathrm{cc}}$ hos personer med økt genetisk risiko og diabetesassosierte autoantistoffer tyder på at en del barn og unge utvikler diabetes med $\mathrm{HbA}_{\mathrm{c}}$-verdier lavere enn 6,5\% (9). Barn og unge har ofte moderate metabolske forandringer i flere måneder før klinisk debut (10), og en ikke ubetydelig andel kan få diagnosen uten typiske symptomer (11).

\section{Diabetesautoimmunitet som diagnose}

Barn som deltar i studier med screening for diabetesassosierte autoantistoffer, kan oppdages tidligere i sykdomsforløpet og har redusert risiko for ketoacidose ved diagnosetidspunktet (12). Gjennom måling av diabetesassosierte autoantistoffer (antiinsulin, anti-GAD, anti-IA2, anti-ZnT8) er det nå mulig å oppdage forstadier til diabetes lenge før det oppstår metabolske forandringer. Den positive og negative prediktive verdien av en enkelt test for autoantistoffer er avhengig av mange faktorer, og en av de viktigste er om man er vedvarende positiv.

De som vedvarende har minst to typer diabetesassosierte autoantistoffer, har svært høy risiko for å utvikle type 1-diabetes i løpet av de påfølgende årene. Risikoen for klinisk type 1diabetes er omtrent $40 \%$ etter fem år for de som utvikler mer enn ett autoantistoff før fem års alder, og nesten alle får type 1-diabetes innen 20 år $(12,13)$. Disse studiene har gitt oss grunnleggende ny innsikt i det naturlige forløpet ved type 1-diabetes.

Hovedformålet med de fleste av disse studiene er å finne risikofaktorer for sykdommen. $\emptyset \mathrm{kt}$ diabetesinsidens de siste fire tiårene kan tyde på at det foreligger ukjente miljømessige årsaker. Forhåpentligvis kan man i fremtidig forskning indentifisere modifiserbare risikofaktorer.

\section{Forebygging av forsinket diagnose}

Enkelte eksperter har foreslått befolkningsbasert screening med diabetesassosierte autoantistoffer (13) og å definere asymptomatisk diabetesautoimmunitet som en diagnose (14). Vi mener det er galt å klassifisere diabetesautoimmunitet som en diagnose (15). Den viktigste grunnen er at vi i dag ikke har noen behandling for å bremse progresjon fra autoimmunitet til klinisk diabetes. Flere kliniske forsøk som tok sikte på å bremse slik progresjon, kunne ikke vise effekt (16). Et annet problem er at det kan gå mange år fra påvisning av autoimmunitet til klinisk debut.

De siste årene har man prøvd ut flere former for immunmodulerende terapi hos pasienter med type 1-diabetes, men resultatene fra denne typen studier har også vært skuffende (17).

\section{Forebygging}

I noen tilfeller har pasienter med klassiske symptomer ventet lenge med å kontakte lege. Derfor kan det være aktuelt å prøve ut tiltak rettet mot befolkningen generelt for å øke kunnskapen om diabetessymptomer. Imidlertid har vi også holdepunkter for å si at 
forsinkelse i noen tilfeller oppstår i helsetjenesten.

Vi har her fokusert på type 1-diabetes hos barn og unge, men vil også minne om at type 1diabetes kan oppstå i alle aldre. Hos voksne ser man ofte en mindre akutt debut. For voksne som har fått diabetesdiagnosen, men der det er uklart som det er snakk om type 1-diabetes eller type 2-diabetes, er det viktig å måle diabetesautoantistoffer, særlig anti-GAD. Det finnes imidlertid lite forskning på det naturlige forløpet før diagnosen ved type 1-diabetes hos voksne.

Vi tror det er mulig å redusere andelen barn og unge som har diabetisk ketoacidose ved diagnostiseringstidspunktet av type 1-diabetes. Dette kan oppnås blant annet gjennom økt oppmerksomhet om tidlige symptomer, både i befolkningen og i helsevesenet, og med rask diagnostikk og henvisning ved mistanke om diabetes.

\section{LITTERATUR:}

1. World Health Organization. Use of glycated haemoglobin (HbAic) in the diagnosis of diabetes mellitus. Geneva: World Health Organization, 2011.

http://www.who.int/diabetes/publications/report-hba1c_2011.pdf(12.2.2018).

2. Berg JP, Hanssen KF, Bjerve KS et al. Standardisert hemoglobin A1c til diagnostisk bruk? Tidsskr Nor Legeforen 2011; 131:565- 6. [PubMed][CrossRef]

3. American Diabetes Association. Diagnosis and classification of diabetes mellitus. Diabetes Care 2014; 37 (suppl 1): S81-90. 10.2337/dc14-So8124357215[PubMed][CrossRef]

4. Craig ME, Jefferies C, Dabelea D et al. ISPAD Clinical Practice Consensus Guidelines 2014. Definition, epidemiology, and classification of diabetes in children and adolescents. Pediatr Diabetes 2014; 15 (suppl 20): 4-17. [PubMed][CrossRef]

5. Norsk barnelegeforening. Akuttveileder i pediatri: Diabetes, nyoppdaget. 2013.

http://www.helsebiblioteket.no/retningslinjer/akuttveileder-i-pediatri/endokrinologi/diabetes-nyopp daget (12.2.2018).

6. Wolfsdorf JI, Allgrove J, Craig ME et al. ISPAD Clinical Practice Consensus Guidelines 2014. Diabetic ketoacidosis and hyperglycemic hyperosmolar state. Pediatr Diabetes 2014; 15 (suppl 20): 154 - 79 . [PubMed][CrossRef]

7. Skrivarhaug T, Kummernes SJ, Drivvoll AK. Barnediabetesregisteret. Årsrapport 2016. Oslo: Oslo universitetssykehus, 2017.

https:/|oslo-universitetssykehus.no/Documents/Barnediabetesregisteret/\%C3\%85rsrapport\%202016\%20 BDR.pdf(13.2.2018).

8. Skrivarhaug T, Drivvoll AK, Kummernes SJ et al. Diabetic ketoacidosis (DKA) at presentation of childhood-onset type 1 diabetes (T1D) in the Nordic countries in 2010-2014 - data from the Danish (DanaKid), Iceland, Norwegian (NCDR) and Swedish (Sweadiabkids) nationwide, childhood diabetes registries. Pediatr Diabetes 2017; 18 (suppl S25): 29.

9. Vehik K, Cuthbertson D, Boulware D et al. Performance of HbAic as an early diagnostic indicator of type 1 diabetes in children and youth. Diabetes Care 2012;35: 1821 - 5. [PubMed][CrossRef]

10. Stene LC, Barriga K, Hoffman M et al. Normal but increasing hemoglobin Aic levels predict progression from islet autoimmunity to overt type 1 diabetes: Diabetes Autoimmunity Study in the Young (DAISY). Pediatr Diabetes 2006; 7: 247 - 53. [PubMed][CrossRef]

11. Triolo TM, Chase HP, Barker JM. Diabetic subjects diagnosed through the Diabetes Prevention TrialType 1 (DPT-1) are often asymptomatic with normal A1C at diabetes onset. Diabetes Care 2009; 32: 769 73. [PubMed][CrossRef]

12. Elding Larsson H, Vehik K, Bell R et al. Reduced prevalence of diabetic ketoacidosis at diagnosis of type 1 diabetes in young children participating in longitudinal follow-up. Diabetes Care 2011; 34: 234752. [PubMed][CrossRef]

13. Ziegler AG, Bonifacio E, Powers AC et al. Type 1 diabetes prevention: a goal dependent on accepting a diagnosis of an asymptomatic disease. Diabetes 2016; 65:3233 - 9. [PubMed][CrossRef] 
14. Bonifacio E, Mathieu C, Nepom GT et al. Rebranding asymptomatic type 1 diabetes: the case for autoimmune beta cell disorder as a pathological and diagnostic entity. Diabetologia 2017; 60:35 - 8 . [PubMed][CrossRef]

15. Knip M, Selvenius J, Siljander H et al. Reclassification of asymptomatic beta cell autoimmunity: a critical perspective. Diabetologia 2017; 60:39 - 42. [PubMed][CrossRef]

16. Näntö-Salonen K, Kupila A, Simell S et al. Nasal insulin to prevent type 1 diabetes in children with HLA genotypes and autoantibodies conferring increased risk of disease: a double-blind, randomised controlled trial. Lancet 2008; 372: 1746 - 55. [PubMed][CrossRef]

17. Wherrett DK, Bundy B, Becker DJ et al. Antigen-based therapy with glutamic acid decarboxylase (GAD) vaccine in patients with recent-onset type 1 diabetes: a randomised double-blind trial. Lancet 2011; 378:319 - 27. [PubMed][CrossRef]

Publisert: 19. mars 2018. Tidsskr Nor Legeforen. DOI: 10.4045/tidsskr.17.0935

Mottatt 27.10.2017, første revisjon innsendt 23.1.2018, godkjent 13.2.2018.

(C) Tidsskrift for Den norske legeforening 2020. Lastet ned fra tidsskriftet.no 